\title{
is Research Square \\ Manganese Limitations and the Enhanced Soil Carbon Sequestration of Temperate Rainforests
}

J Marty Kranabetter ( $\nabla$ marty.kranabetter@gov.bc.ca )

British Columbia Ministry of Forests https://orcid.org/0000-0001-9255-1210

Tim Philpott

BC Ministry of Forests: British Columbia Ministry of Forests Lands Natural Resource Operations and Rural Development

Dave Dunn

Pacific Forestry Centre

\section{Research Article}

Keywords: Mn-peroxidase, podzolization, decomposition, Agaricomycete fungi, forest soils

Posted Date: June 22nd, 2021

DOI: https://doi.org/10.21203/rs.3.rs-629100/v1

License: (c) (1) This work is licensed under a Creative Commons Attribution 4.0 International License. Read Full License

Version of Record: A version of this preprint was published at Biogeochemistry on August 18th, 2021. See the published version at https://doi.org/10.1007/s10533-021-00840-5. 


\section{Abstract}

Manganese ( $\mathrm{Mn}$ ) has been identified as a regulatory bottleneck in carbon (C) turnover because of its role as an enzymatic co-factor in the oxidative decomposition of $\mathrm{C}$ by $\mathrm{Mn}$-peroxidase $(\mathrm{MnP})$. We tested this limit on decay using forest soils from coastal British Columbia with contrasting Mn concentrations. Moderately weathered soils (Brunisols) had an average 3.6fold increase in $\mathrm{MnP}$ activity within the upper soil profile in comparison to highly weathered Podzols. Ordination of the Agaricomycete fungal community, which are responsible for MnP production, confirmed significant differences in assemblages between soil types for saprotrophic fungi, particularly species within Agaricales, Trechisporales and Auriculariales. Ectomycorrhizal fungi of Pseudotsuga menziesii were equally aligned with soil type and select taxa more abundant on Brunisols may have supplemented MnP activity. A laboratory incubation with an Mn amendment produced significant interactions in MnP activity by soil type. Surprisingly, MnP activity of both Brunisol substrates declined substantially with an amendment (-56\% and $-40 \%$ for forest floor and mineral soil, respectively), in contrast to Podzols $(-30 \%$ and $+26 \%$, respectively). This inhibitory response was linked to considerable uptake of the added Mn in Brunisols, and underscores how $\mathrm{Mn}^{2+}$ likely operates directly on fungi as a regulator of $m n p$ transcription for MnP production. Our study highlights a new perspective concerning the abiotic drivers underpinning the expansive soil $\mathrm{C}$ stocks across perhumid temperate rainforests of the Pacific Northwest.

\section{Introduction}

Empirical models of soil organic carbon (SOC) turnover and sequestration are increasingly recognizing an important role for manganese $\left(\mathrm{Mn}^{2+}\right)$, which is a co-factor for an enzyme, Mn-peroxidase (MnP), involved in oxidative decomposition of organic matter (Berg et al. 2015; Stendahl et al. 2017; Keiluweit et al. 2015; Jones et al. 2020). Mn-peroxidases and other class II secretory fungal peroxidases are produced almost exclusively by fungi from the class Agaricomycete, a large and diverse group that includes both free living saprotrophic and symbiotic ectomycorrhizal species (Morgenstern et al. 2008; Floudas et al. 2012; Kellner et al. 2014). The apparent gains in SOC with diminishing Mn availability is of interest both in better understanding abiotic mechanisms influencing decomposition (Rasmussen et al. 2018), and because enhanced sequestration of SOC is an important mitigation strategy in combatting climate change (Lal 2004). Widespread increases in $\mathrm{SOC}$ could in theory greatly offset greenhouse gas $\mathrm{CO}_{2}$ emissions, and a large effort is collectively underway to examine how land use and management practices, such as afforestation, tree species selection and retention of harvest residues, might influence soil C stocks (Jandl et al. 2007; Jastrow et al. 2007; Mayer et al. 2020). More direct interventions, such as applications of biochar or crushed basalt to soils, have also drawn attention for their potential in enhancing SOC storage (Beerling et al. 2018). As a potential key driver of decomposition and organic matter accumulation it is therefore worth considering whether management systems affecting Mn availability might prove to be another avenue for influencing SOC sequestration.

The initial evidence for the role of $\mathrm{Mn}$ in SOC cycles came from litter decomposition studies where mass loss rates were positively correlated to initial Mn concentrations of needles and leaves (Berg et al. 1996; Berg et al. 2010). Across northern latitudes there is further correlative evidence that SOC accumulation, particularly organic horizons (forest floors), increases with declining exchangeable Mn (Stendahl et al. 2017; Kranabetter 2019; Andrieux et al. 2020). In landscapes with substantial nitrogen $(\mathrm{N})$ pollution and poorly-buffered soils, such as parts of the eastern United States, the enhanced accumulation of SOC observed with $\mathrm{N}$ deposition has similarly been linked to a reduction in Mn availability (van Diepen et al. 2015; Whalen et al. 2018), with polluted soils lacking some of the Agaricomycetes likely responsible for MnP production (Edwards et al. 2011; Morrison et al. 2016; Entwistle et al. 2018b). Recent work has also linked the abundance of reactive $\mathrm{Mn}^{3+}$ species to oxidative activity and subsequent depolymerization of aromatic $\mathrm{C}$ near dense fungal hyphae in mineral soils (Jones et al. 2018). Besides acting as an enzymatic co-factor, it should be noted that $\mathrm{Mn}^{2+}$ also plays a related function with fungi as a regulator of transcriptase activity for ligninolytic peroxidase production (Brown et al. 1990; Inhansson et al 2nก2) I ahoratorv cultures of wond-decay fungi have demonstrated an influence of $\mathrm{Mn}^{2+}$ concentrations Loading [MathJax]/jax/output/CommonHTML/fonts/TeX/fontdata.js 
in the growing medium on the expression of MnP, emphasizing a degree of sensitivity of these fungi to Mn levels in the environment (Gettemy et al. 1998; Ben Hamman et al. 1999).

Perhumid temperate rainforests of the Pacific northwest coast of North America have some of the densest SOC content found globally, with stocks often $>300 \mathrm{Mg} \mathrm{C} \mathrm{ha}^{-1}$ (Scharlemann et al. 2014; Carpenter et al. 2014; McNicol et al. 2019). This feature of coastal soils, as compared to forests under less humid continental climates, has been generally attributed to greater forest productivity and lower decomposition rates under limited soil oxygen availability (Sun et al. 2004). Another consideration is whether the unique soil geochemistry of temperate rainforests affects decomposition rates, particularly the highly weathered Ferro-Humic Podzols common to coastal British Columbia (Sanborn et al. 2011). An edaphic gradient caused by contrasting precipitation levels across southern Vancouver Island, for example, displayed an exponential increase in SOC with diminishing Mn that was attributed to soil podzolization (Kranabetter 2019). A potential difficulty with this correlative evidence, however, is the possibility that Mn serves as a proxy for a number of influential changes in soil or ecosystem properties, rather than being the underlying cause of reduced decomposition rate. Further investigation is needed to examine how well MnP activity and Agaricomycete fungal communities align with soil Mn availability, and to experimentally test the soil biological response to an $\mathrm{Mn}$ amendment. This latter approach has been previously employed with litterbag studies, lending support to the role of $\mathrm{Mn}$ in the decay of amended litter (Trum et al. 2015; Sun et al. 2019).

In this study we examined the relationship between $\mathrm{Mn}$ and SOC across temperate rainforests in more detail with MnP assays and sequencing of fungal communities between Brunisols (low SOC - high Mn) and Podzols (high SOC - low Mn) (Kranabetter 2019). We then incubated these contrasting soils with an Mn amendment in the laboratory to test the effect on $\mathrm{MnP}$ activity and fungal biomass. As a second treatment we used a soil slurry derived from fresh Brunisol soil to provide fungal inoculum on the supposition that key Agaricomycete fungi excluded from Podzols could potentially mute the enzymatic response to added Mn. Our hypotheses were that 1) Podzols would have lower concentrations of MnP than Brunisols, along with a unique Agaricomycete flora, for both forest floor and mineral substrates; and 2) Podzols would have an increase in $\mathrm{MnP}$ activity with an $\mathrm{Mn}$ amendment, more so where an inoculum was included, whereas Brunisols would display no response to these treatments. The objective of our study was to provide collaborative evidence for the key role of exchangeable Mn and fungi in SOC cycles of these coastal soils, and to illustrate how management practices affecting Mn availability could be one avenue towards enhancing soil $\mathrm{C}$ sequestration.

\section{Materials And Methods}

\section{Site descriptions}

The study plots were a subset of sites (10 in total) across southern Vancouver Island described previously that encompass a precipitation gradient created by an orographic rainshadow (Kranabetter et al. 2019; Kranabetter 2019). We selected five plots from the east side of the Island, characterized by less weathered soils ('Brunisol', equivalent to Inceptisol or Cambisol; Soil Classification Working Group 1998) under a dry, maritime climate (average mean annual precipitation [MAP] and temperature [MAT] of $1375 \mathrm{~mm}$ and $8.6^{\circ} \mathrm{C}$, respectively), and five plots from the west side of the Island (average MAP = $3310 \mathrm{~mm}, \mathrm{MAT}=8.5^{\circ} \mathrm{C}$ ) with strongly podzolized soils ('Podzol' or Spodosol). All plots were low elevation, second-growth Pseudotsuga menziesii var. menziesii ([Marb.] Franco) plantations, 40 to 60 years in age, that had been clearcut logged and broadcast burned. Average site index (height at 50 years in age), based on 5 co-dominant trees per plot, was $38.2 \mathrm{~m}$ (SE 2.0) and $37.4 \mathrm{~m}(0.9)$ across Brunisol and Podzol plots, respectively. Select soil properties averaged by substrate are shown

in Table 1, while P. menziesii needle nutrient concentrations are shown in Supplemental Table 1 (see Kranabetter et al. 2019 for methodology details).

Soil sampling for enzyme and fungal community analysis

In late spring of 2019 (June 3-6) we returned to the 10 plots to obtain fresh forest floors and 0-20 cm mineral soils for an Loading [MathJax]/jax/output/CommonHTML/fonts/TeX/fontdata.js hg with enough soil for a laboratory incubation (see Supplemental 
Methods). Two subsamples of fresh, sieved soil of approximately $150 \mathrm{ml}$ from each of the three composited samples per substrate were frozen at $-20^{\circ} \mathrm{C}$ for an enzyme assay and DNA extraction. The assay method for Mn-dependent peroxidase activity was based on oxidative coupling of DMAB (3-dimethylaminobenzoic acid) and MBTH (3-methyl-2-

benzothiazolinone hydrazone hydrochloride) in the presence of $\mathrm{Mn}^{2+}$ and $\mathrm{H}_{2} \mathrm{O}_{2}$, as developed for forest soils by Kyaschenko et al. (2017) (see Supplemental Methods). The residual peroxidase activity not dependent on Mn as a cofactor was subtracted based on reactions in which $\mathrm{MnSO}_{4}$ was replaced by a chelator $\left(2 \mathrm{mM} \mathrm{Na}-\mathrm{EDTA}-2 \mathrm{H}_{2} \mathrm{O}\right)$. Substrate controls for background absorption unrelated to enzyme activity were supernatants plus reaction solutions without $\mathrm{H}_{2} \mathrm{O}_{2}$, while boiled samples were used as negative controls to confirm enzyme involvement in the colour change. Enzyme activity was expressed as $\mu \mathrm{mol} \mathrm{h} \mathrm{h}^{-1} \mathrm{~g}^{-1}$ dry soil for both substrates.

DNA from soil and forest floor material was extracted using the Qiagen DNeasy PowerSoil kit (Cat No. 12888, Hilden, Germany) following manufacturer instructions (see Supplemental Methods). The full length ITS region (SSU + ITS1 + 5.8S + ITS2 + LSU) was amplified in duplicate from template DNA using high-fidelity Phusion polymerase and fusion primers (PacBio adaptors + barcodes + primers). Sequences were quality filtered and binned into amplicon sequence variants (ASVs) using the DADA2 software package in R (Callahan et al. 2016) (see Supplemental Methods).

Soil incubation study

The laboratory incubation study was designed as a two-way factorial. The first treatment was a Mn amendment to increase exch. Mn concentrations of Podzols to approximate that of Brunisols. This was determined, on average, to be equal to 750 $\mathrm{mg} \mathrm{Mn} \mathrm{per} \mathrm{kg}^{-1}$ forest floor and $150 \mathrm{mg} \mathrm{Mn} \mathrm{per} \mathrm{kg}^{-1}$ mineral soil (as per Table 1, cmol equivalent charge of $\mathrm{Mn}^{2+}$ with atomic mass of 54.9 and two valence electrons). We added $76.0 \mathrm{mg}$ of $\mathrm{MnSO}_{4}{ }^{+} 4 \mathrm{H}_{2} \mathrm{O}$ to supply $18.75 \mathrm{mg} \mathrm{Mn}$ to each jar of forest floor (25 g dry wt equivalent) and $60.8 \mathrm{mg} \mathrm{MnSO}_{4}{ }^{+} 4 \mathrm{H}_{2} \mathrm{O}$ to provide $15.0 \mathrm{mg} \mathrm{Mn}$ to each jar of mineral soil (100 g dry wt equivalent). The second treatment was a microbial inoculum to provide an opportunity for fungi of Brunisol soils to colonize Podzol soils. Approximately $125 \mathrm{ml}$ of the fresh Brunisol soils from each of the 5 sites, both as mineral soil and forest floor, were added to a large glass Erlemeyer flask with $2 \mathrm{~L}$ of distilled water. After gently shaking for 10 minutes, the slurry was poured through a sterilized cheesecloth to remove the solids. This procedure was then repeated, and the second slurry was autoclaved at $120^{\circ} \mathrm{C}$ for one hour to serve as a control. The four jars of mineral soil and four jars of forest floor per plot were then allocated one combination of the 2-way factorial: $20 \mathrm{ml}$ of the fresh slurry water/sterilized slurry water with or without the $\mathrm{MnSO}_{4}{ }^{+} 4 \mathrm{H}_{2} \mathrm{O}$ amendment. The jars were kept at $20^{\circ} \mathrm{C}$ for 15 weeks, after which two subsamples were extracted and frozen at $-20^{\circ} \mathrm{C}$ for enzyme and ergosterol analysis, while the remaining soil was air-dried, ground and sieved $(2 \mathrm{~mm})$ for an analysis of exch. Mn concentrations (see Supplemental Methods).

\section{Statistics}

With fresh field soils we assayed 3 subsamples per composite for peroxidase activity (= 9 readings), and averaged these by composite for the statistical analysis ( $n=3$ per substrate per plot, for a total of 57 because of one Brunisol site with no forest floor). The differences in Mn-peroxidase activity between soil type (Brunisol/Podzol) and substrates (forest floor/mineral soil) were tested by a linear mixed effect model in SAS (Mixed Procedure, Method = REML) (SAS Institute 2021), with study sites nested within soil type as a random effect. Due to a greater degree of residual variation for enzyme activity among Brunisol sites compared to Podzol sites, the model allowed each soil type to have a separate residual variance component. For the soil incubation study we used a completely randomized split-plot design with soil type as the main-plot factor and $\mathrm{Mn}$ amendment/inoculum as fully crossed split-plot factors. For this study we assayed 3 subsamples per jar, and averaged these readings for the statistical analysis ( $n=40$ for mineral soils, and 36 for forest floors because of one Brunisol site with no forest floor). Each substrate (forest floor/mineral soil) was tested separately, and the model again allowed each soil type to have a separate residual variance component.

Loading [MathJax]/jax/output/CommonHTML/fonts/TeX/fontdata.js 
Each of the three substrate samples per plot were extracted for DNA and the fungal species data averaged at the plot level for statistical analysis ( $n=19$ because of one Brunisol site with no forest floor). All multivariate analysis was conducted in R ( $v$ 4.0.3, R Core Team 2020). Fungal communities were examined for soil type and substrate effects using distance-based redundancy analysis based on Bray-Curtis dissimilarities using the $d b r d a$ function in the software package vegan (Oksanen et al. 2019, v 2.5-6). Ordinations were produced for subsets of the fungal community: all fungi, all saprotrophs, all ectomycorrhizae, all Agaricomycetes, saprotrophic Agaricomycetes, and ectomycorrhizal Agaricomycetes. Soil type and substrate effects on the fungal community and subsets therein were tested using permutational multivariate analysis of variance (PERMANOVA) via the adonis2 function (McArdle and Anderson 2001). The response of individual taxa and/or select groups of saprotrophic Agaricomycetes to soil type and substrate were modelled using a multivariate generalized linear model with the manyglm function in the mvabund package (Wang et al. 2020). Models were fit using a negative binomial distribution with an offset to account for variation in sampling depth. Multivariate and univariate fitted models were tested for significance using the anova.manyglm function and the likelihood ratio test statistic. Unadjusted p-values are reported for univariate results. Responses of individual species or groups were visualized using univariate regression coefficients extracted from the manyglm output.

\section{Results}

\section{Soil and foliar properties}

As reported previously (Kranabetter 2019), Podzol plots had deeper forest floors and greater C concentrations in upper mineral soils than Brunisols, alongside large reductions in exch. Mn (Table 1). Both Podzol substrates had a lower pH than Brunisols, albeit less significantly for mineral soils (Table 1). We also note enhanced concentrations of exch. Al $+\mathrm{Fe}$ and large reductions in inorganic $\mathrm{P}$ with podzolization. Total $\mathrm{N} \%$ was greater across Podzol plots but C:N ratios were equivalent between soil types for both substrates (Table 1). Soils were consistently loam in texture across plots, averaging $51 \%$ (SE 1.2) sand, $39 \%$ (1.1) silt, and $11 \%(0.5)$ clay (soil type $p$ value $=0.81,0.94$, and 0.48 , respectively). Foliar analysis confirmed a significant decline of almost $60 \%$ in Mn concentrations of $P$. menziesii needles between Brunisols $\left(576 \mathrm{mg} \mathrm{kg}^{-1}\right)$ and Podzols (244 $\mathrm{mg} \mathrm{kg}^{-1}$ ), but with no differences in foliar $\mathrm{N}$ concentrations (1.23\%) (Supplemental Table 1).

Field soil enzyme activity and fungal communities

With field soils there was significantly more MnP activity in both substrates of Brunisols compared to Podzols (Fig. 1), equal to a 3.6-fold increase overall (3.8 $\times$ for mineral soil, $3.4 \times$ for forest floors) (Soil type $p=0.002$, Substrate $p=0.048$ [mineral soil $>$ forest floor], Soil type $\times$ Substrate $p=0.203$ ).

Fungal communities of field soils were very diverse, encompassing 14 identified Phyla, 38 Classes and 81 Orders. PERMANOVA revealed significant differences $(p<0.001)$ in fungal species composition between soil types at all levels of delineation (Supplemental Table 2). For the subset of Agaricomycete fungi we found almost 500 species in the combined saprotrophic and ectomycorrhizal fungal communities, which were clearly aligned by soil type $(p<0.001)$ and, to a lesser degree, substrate $(p=0.028)$ (Fig. 2). In testing the distribution of select, diverse groups of Agaricomycete saprotrophs we found the overall model, based on 7 groups and 139 spp., to be weakly significant ( $\mathrm{Dev}=19.06, p=0.067)$ by soil type (Fig. 3). Brunisols were characterized by a greater abundance of species from the Order Trechisporales (Dev $=4.03, p=$ 0.054), along with some common terrestrial saprotrophic genera of Agaricales (e.g., Clitocybe, Lepiota, Gymnopus) (Dev = 3.54, $p=0.046)$. The genus Mycena was not skewed to either soil type as a group but a number of species were more prevalent on Brunisols (Fig. 3,4). Likewise, individual species of Auriculariales were more abundant on Brunisols, such as Pseudohydnum gelatinosum (Fig. 4), but overall there was no clear distinction between soil type for this Order (Fig. 3). Podzols, in contrast, had significantly more species within the family Strophariaceae (Dev = 8.33, $p=0.019)$, particularly Galerina (Fig. 3, 4). Some key genera more closely associated with Brunisols amongst ectomycorrhizal fungi included 
Cortinarius and Piloderma, along with many individual species of, for example, Russula, Inocybe and Lactarius (Supplemental Fig. 1).

Incubation of soils with $\mathrm{Mn}$ amendment

After a 15 week incubation, we found significant interactions in $\mathrm{MnP}$ activity with soil type that indicated contrasting responses to amended $\mathrm{Mn}$. With forest floors, the addition of $\mathrm{Mn}$ caused a significant reduction in $\mathrm{MnP}$ activity, but more so for Brunisols than Podzols (56\% vs $30 \%$ decrease, respectively) (Fig. 5a, Table 2). Mineral soils, in contrast, had opposing responses in MnP, as Brunisols declined by $40 \%$ while Podzols increased by $26 \%$ with the Mn amendment (Fig. 5b, Table 2). The inoculum treatment had no detectable effect on MnP in either substrate (Table 2). Fungal biomass, as quantified by ergosterol concentrations, was not affected by the Mn amendment nor inoculum treatment for either substrate (Supplemental Table 3). Brunisols, however, had significantly more ergosterol than Podzols in both forest floors (78 vs. 28 $\mathrm{mg} \mathrm{kg}^{-1}$, respectively; $p=0.011$ ) and mineral soils (5.7 vs. $2.8 \mathrm{mg} \mathrm{kg}^{-1}$, respectively; $\left.p=0.015\right)$.

We ratified the efficacy of the $\mathrm{Mn}$ amendment by comparing exchangeable $\mathrm{Mn}$ concentrations after the 15 week incubation. Clear distinctions in the fate of the added Mn were apparent between soil types (Table 2, Fig. 6). The forest floors and mineral soils of Podzols had substantial increases in exch. Mn, approximating that of the unamended Brunisols, as expected (Fig. 6a,b). Brunisols, in contrast, showed much more subdued increases in exch. Mn concentrations across both substrates ( $9 \%$ and $55 \%$ increase for forest floors and mineral soils, respectively), far less than the two-fold increase theoretically possible under the amendment regime (Fig. 6a,b).

\section{Discussion}

Collectively the patterns established from these contrasting field soils, and their response to $\mathrm{Mn}$ amendment, lends strong support to our hypothesis of a biologically distinct character for Brunisols vs. Podzols related to geochemistry and SOC cycles. In particular, Podzols had considerably less MnP activity in both substrates compared to Brunisols, and hosted a distinct Agaricomycete fungal community despite the consistency in forest stand composition, age and disturbance history across the edaphic gradient. A significant decrease in foliar Mn concentrations of $P$. menziesii across Podzol sites was confirmed, which would be consistent with reduced mass loss rates during litter decay (Berg et al. 1996; Davey et al. 2007; Perakis et al. 2012). We also found significant interactions with the Mn amendment, both in MnP activity and the fate of the added $\mathrm{Mn}$, which indicated contrasting functional responses by the opposing soils. There was no evidence these geochemical effects on SOC were related to differing clay content (Doetterl et al. 2015), which was generally low (11\%) across the gradient. Our study results bring a new perspective concerning the abiotic drivers underpinning the large, expansive soil $\mathrm{C}$ stocks across perhumid temperate rainforests of the Pacific west coast (Carpenter et al. 2014; McNicol et al. 2019) and lend support to $\mathrm{C}$ models inclusive of $\mathrm{Mn}$ as a regulatory bottleneck in organic matter accumulation (Berg and McClaugherty 2014; Stendahl et al. 2017).

Distinctions between Brunisols and Podzols in field assays

Much of research into peroxidase enzymes has focused on litter layers and organic horizons (Berg et al. 2015), but these decay processes in temperate forests clearly extend into mineral soils as well. Jones et al. (2020) proposed a useful distinction in oxidative decomposition processes, which would vary between Mn (peroxidases produced by white-rot fungi) and Fe agents (Fenton reaction via brown-rot fungi) depending on which element is most abundant. In this respect our field soil assays would be in agreement, as exch. Mn was more abundant than exch. Fe in both forest floor and mineral soil substrates of Brunisols, whereas Fe, in turn, dominated the Podzol soil profile (Table 1). Brown-rot fungi are thought to be incapable of fully oxidizing lignin (Worrall et al. 1997; Berg and McClaugherty 2014), and possibly similar aromatic C compounds found in humus, which would help explain how reductions in MnP and related class II peroxidase enzyme activity can lead to the inverse correlations between SOC and exch. Mn (Stendahl et al. 2017; Kranabetter 2019; Andrieux et

Loading [MathJax]/jax/output/CommonHTML/fonts/TeX/fontdata.js 
The distinctive ability of soil and litter Agaricomycete fungi to decompose SOC using oxidative enzymes is typically attributed to the free-living saprotrophic species (Steffen et al. 2000; Kellner et al. 2014; Maaroufi et al. 2019). Given the considerable diversity in taxa it can be challenging to identify which of these species are key contributors of MnP, even for closely related species (Vares and Hatakka 1997), and especially as the functional guild classification for many soil fungi are ambiguous or untested (Riley et al. 2014; Talbot et al. 2015; Entwistle et al. 2018a). Previous field studies and forays in this area (Kranabetter et al. 2019) have consistently shown greater abundance of some common terrestrial saprotrophic species (Clitocybe, Lepiota, Gymnopus) on Brunisols, as was confirmed here with molecular techniques. In addition to these Agarics, some lesser known taxa within the Trechisporales were more frequent in Brunisols, along with individual species of Auriculariales, and could represent other important white-rot fungi of soils. Mn-peroxidase activity in Brunisols was significantly higher overall than Podzols but also more variable, with subsamples up to $50 \mu \mathrm{mol} \mathrm{h}^{-1} \mathrm{~g}^{-1} \mathrm{dry}$ soil, and these hotspots suggest a mosaic of Agaricomycete fungal populations that may ebb and flow as $\mathrm{C}$ is deposited and decayed (i.e., 'foraging'; Watkinson et al. 2006). Our presumption here is that the reductions in MnP activity across Podzols reflects the absence of key fungi, and likely a functional shift from lignolytic to cellulolytic fungi (Entwistle et al. 2018b), although it is possible that the efficacy of shared fungal species is also reduced in Podzols because of a downregulation in gene expression (Zak et al. 2019) with lower Mn concentrations in litter and soils.

Temperate forests across southern Vancouver Island are predominantly conifers with ectomycorrhizal fungi (primarily Pseudotsuga menziesii and Tsuga heterophylla), along with a minor arbuscular component (Thuja plicata) (Brown and Hebda 2002). Mycorrhizal fungi provide an important source of $C$ to forest soils (Frey 2019), but given the historic uniformity in stand composition these differential patterns in SOC are unlikely to reflect mycorrhizal type per se as described elsewhere (Taylor et al. 2016; Craig et al. 2018). It should be noted, however, that ectomycorrhizal fungal communities were equally distinct as saprotrophic communities between soil types, in part due to adaptations required for organic phosphorus (P) acquisition on Podzols (Meeds et al. 2021). While select ectomycorrhizal species of Podzols displayed some capacity for laccase production (Meeds et al. 2021), other ectomycorrhizal genera more common to Brunisols, such as Cortinarius and Piloderma, could potentially contribute alongside saprotrophic fungi to the differences in peroxidase activity of these substrates, thereby supplementing the long-term oxidation rates of SOC (Bödeker et al. 2014; Sterkenburg et al. 2018).

Biological response to an Mn amendment

The significant interaction of soil types to an Mn amendment was consistent with our hypothesis as it affirms a strong effect of $\mathrm{Mn}$ availability on decay processes related to soil podzolization. The large negative response of added $\mathrm{Mn}$ on Brunisol MnP activity was unexpected, however, as we assumed there would be little influence of Mn beyond a threshold displayed in the exponential relationships (approx. $10 \mathrm{mmol} \mathrm{kg} \mathrm{C}^{-1}$ or $30 \mathrm{~kg} \mathrm{Mn} \mathrm{ha}^{-1}$; Stendahl et al. 2017; Kranabetter 2019). In retrospect this suppression might have been anticipated as culture studies of wood-rot fungi under increasing Mn concentrations have demonstrated an inhibitory response as well (Bonnarme and Jeffries 1990; Buswell et al. 1995), underscoring how $\mathrm{Mn}^{2+}$ directly regulates $\mathrm{MnP}$ expression by differentially activating the transcription of $m n p$ genes (Gettemy et al. 1998; Cohen et al. 2001; Johansson et al. 2002). The greater sensitivity of Brunisols to Mn concentrations was further illustrated by the subsequent removal of much of the amendment, particularly in forest floors, which we suspect was via uptake by the saprotrophic fungal biomass. It was postulated that some saprotrophic fungi have an exceptionally high demand for Mn, as reflected by elevated Mn concentrations in fruiting bodies (Kranabetter 2019). The instantaneous surge in $\mathrm{Mn}^{2+}$ through an amendment perhaps inundated these Mn-demanding fungi to the point of negatively affecting $m n p$ transcription, resulting in more substantial declines in $\mathrm{MnP}$ for both Brunisol substrates compared to Podzols. It is unlikely this suppression in MnP reflects a toxic effect as the fungal biomass of the incubated soils was not altered by the $\mathrm{Mn}$ amendment. We also note that MnP activity of Brunisol mineral soils after the incubation period was clearly lower than found in fresh soils, possibly due to some combination of physical disruption (through sieving), removal of roots with key MnP-expressing ectomycorrhizal species, or perhaps suboptimal lab conditions (e.g., high soil moisture content).

Loading [MathJax]/jax/output/CommonHTML/fonts/TeX/fontdata.js

Page $7 / 21$ 
In contrast, mineral soils of Podzols had a slight positive response in MnP to the amendment, as would be consistent with the hypothesis of $\mathrm{Mn}$ as the underlying limitation to SOC turnover (see also Trum et al. 2011; Whalen et al. 2018; Subedi et al. 2021). We did not find a similar response with forest floors of Podzols, however, although the inhibition of MnP was at least significantly less substantial than in Brunisol forest floors. Perhaps this suppression of MnP reflects a dose effect where an $\mathrm{Mn}^{2+}$ input of this magnitude, despite low background levels, still negatively affects fungal $m n p$ transcription, and it would be worthwhile testing whether smaller amendments could induce a positive response. There is also the possibility that low inorganic $\mathrm{P}$ availability across Podzols is a co-limitation with $\mathrm{Mn}$ on fungal activity, although in a similar incubation study from the north coast of British Columbia there were only decreases found in microbial respiration and no consistent change in microbial biomass with added $P$ (Kranabetter et al. 2005). Our attempt at an inoculum slurry from Brunisols to establish saprotrophic fungi in Podzols was seemingly unsuccessful, and may require a more substantial intervention, but in theory at least a stronger response to an $\mathrm{Mn}$ amendment in Podzols could hinge upon the presence of appropriate white-rot fungal species for these substrates.

Implications for landscape patterns in SOC

Schmidt et al. (2011) reasoned that the persistence of SOC is not entirely a molecular property but instead an ecosystem feature controlled by environmental factors such as climate, soil acidity, and the soil microbial community. For coastal rainforests of the Pacific Northwest this key ecosystem feature is arguably soil podzolization, which is a consequence of high annual precipitation through medium- to coarse-textured soils, coupled with acidic leachate from coniferous forest cover, ericaceous shrubs and bryophytes (Sanborn et al. 2011). With low levels of exch. Mn we expect less complete decomposition of organic matter, resulting in accumulation of residual $\mathrm{C}$ in humus. Subsequently, $\mathrm{C}$ is transferred as leachate or microbial necromass to the underlying mineral soil where it can be further stabilized in organo-mineral complexes or through other stabilization mechanisms (Buurman and Jongmans 2005; Rasmussen et al. 2018; Lavallee et al. 2020). Potential counterarguments for landscape processes boosting SOC content other than podzolization should be considered. Increased nitrogen availability or forest productivity as a driver of SOC (Berg 2000; Kyaschenko et al. 2017; Sun et al. 2004), for example, is doubtful in this context as there was no indication of broad contrasts in soil fertility across the edaphic gradient, at least as measured by soil C:N ratio, foliar N\% or site index. It is worth noting, however, the widespread, elevated soil $\mathrm{N}$ content of these rainforest Podzols (Kranabetter et al. 2020), which likely reflects the legacy of substantial $\mathrm{N}_{2}$-fixation by red alder (Alnus rubra) (Binkley et al. 1994). Enhanced soil acidification by nitric acid from $\mathrm{N}$-rich alder litter (Perakis and Pett-Ridge 2019) could possibly parallel the edaphic processes under long-term N pollution that can also reduce soil $\mathrm{pH}$ and $\mathrm{Mn}$ availability (Whalen et al. 2018). Red alder and other $\mathrm{N}_{2}$-fixing biota of the perhumid rainforest (epiphytic cyanolichens and cyanobacteria-bryophytes; Antoine 2004; Lindo and Whiteley 2011) could therefore be additional biotic agents contributing to the depletion of exch. Mn across Podzols. We also recognize that the lower frequency of disturbances in perhumid rainforests, particularly wildfire, is not necessarily irrelevant to the accumulation rates of forest floors (Wardle et al. 2012; Andrieux et al. 2018), but all of the study plots were burned after timber harvest and yet the differences in biological properties and $\mathrm{C}$ turnover associated with exch. Mn have persisted throughout the upper soil profile. To be clear, outside of these productive forest stands there are also large areas of low lying scrub forests in the Pacific Northwest with high water tables and deep (> $40 \mathrm{~cm}$ ) organic soils (Sajedi et al. 2012; Kranabetter et al. 2013). Anerobic microsites contribute to longer organic matter residence time (Jones et al. 2018; Keiluweit et al. 2017), and consequently these very wet scrub forests likely have the dual limitations of depleted $\mathrm{Mn}$ and low $\mathrm{O}_{2}$ on decomposition rates.

Under typical forest management we would not be contemplating ways to intervene and disrupt decomposition processes, but with the unprecedented threat of rapid climate change it is vital to evaluate any possible avenue for even small gains SOC stocks that could offset greenhouse gas emissions (e.g., the "4 per 1000" initiative; https://www.4p1000.org/). Some degree of manipulation in soil geochemistry is inadvertently underway already with the boost in SOC and diminished Mn found on poorly-buffered soils with anthropogenic N pollution (Whalen et al. 2018), and perhaps, as we speculated, under Loading [MathJax]/jax/output/CommonHTML/fonts/TeX/fontdata.js 
$\mathrm{N}_{2}$-fixing trees as well (Mayer et al. 2020). If a proportion of exch. Mn can be selectively immobilized from fungal uptake in lightly or moderately weathered soils it may reduce the production and efficacy of peroxidases and boost SOC content. A possibly fortuitous finding of this study is that a similar suppressive effect can evidently be had by simply adding sufficient quantities of $\mathrm{Mn}^{2+}$ to forest soils, which would be technically less challenging, although there are legitimate questions on the duration and unintended consequences of such a treatment. Management practices that can alter Mn availability have not been well explored, nor more direct interventions in Mn supply, but we suggest both opportunities be considered as mitigation strategies.

\section{Declarations}

\section{Acknowledgements}

We thank Jodi Axelson and Dave Goldie (B.C. Ministry of Forests, Victoria) for supporting studies on these long-term experimental plots. Also thanks to Joel Ussery (Capital Regional District, Victoria) for access to the watersheds on eastern Vancouver Island. Kate McKeown, Jillian Wheatley, Mae Frank and Cathy Dang provided valuable support in soil sampling, enzyme assays and DNA extractions. Amber Sadowy and Andre Bindon (B.C. Ministry of Environment Analytical Laboratory) undertook the soil and foliar chemical analysis, while Peter Ott (B.C. Ministry of Forests, Victoria) was consulted on the statistical analysis. The authors also express their appreciation to Julia Kyaschenko and Leticia PérezIzquierdo for their advice on the peroxidase assay methodology, and to Patrick Walters (University of Victoria) for helpful discussions of enzyme biochemistry. Funding for this study provided by the British Columbia Ministry of Forests, Lands and Natural Resource Operations.

Funding: BC Ministry of Forests, Lands and Natural Resource Operations

Conflicts of interest: The authors declare no competing interest

Availability of data and material: soil and enzyme data available at Dryad doi:10.5061/dryad.612jm6436. Sequence data deposited at GenBank with pending accession numbers

Authors' contributions: JMK and TJP conceived the project and designed methodology; JMK, TJP and DED collected study data for analysis; JMK and TJP analysed the data and JMK led the writing of the manuscript. All authors contributed critically to the drafts and gave final approval for publication

\section{References}

Andrieux B, Beguin J, Bergeron Y, Grondin P, Paré D (2018) Drivers of postfire soil organic carbon accumulation in the boreal forest. Glob Change Biol 24:4797-4815

Andrieux B, Paré D, Beguin J, Grondin P, Bergeron Y (2020) Boreal-forest soil chemistry drives soil organic carbon bioreactivity along a 314-year fire chronosequence. Soil 6:195-213

Antonine ME (2004) An ecophysiological approach to quantifying nitrogen fixation by Lobaria oregana. Bryologist 107:8287

Beerling DJ, Leake JR, Long SP, Scholes JD, Ton J, Nelson PN, Bird M, Kantzas E, Taylor LL, Sarkar B, Kelland M, DeLucia E, Kantola I, Müller C, Rau G, Hansen J (2018) Farming with crops and rocks to address global climate, food and soil security. Nat Plants 4:138-147

Ben Hamman O, de la Rubia T, Martínez J (1999) The effect of manganese on the production of Phanerochaete flavido-alba lianinolvtic. nernxidases in nitronen limited cultures FFM.S Microbiol Lett 177:137-142

Loading [MathJax]/jax/output/CommonHTML/fonts/TeX/fontdata.js 
Berg B (2000) Litter decomposition and organic matter turnover in northern forest soils. For Ecol Manag 133:13-22.

Berg B, Davey MP, De Marco A, Emmett B, Faituri M, Hobbie SE, Johansson M-B, Liu C, McClaugherty C, Norell L, Rutigliano FA, Vesterdal L, Virzo De Santo A (2010) Factors influencing limit values for pine needle litter decomposition: a synthesis for boreal and temperate pine forest systems. Biogeochemistry 100:57-73

Berg B, Erhagen B, Johansson M-B, Nilsson M, Stendahl J, Trum F, Vesterdal L (2015) Manganese in the litter fall-forest floor continuum of boreal and temperate pine and spruce forest ecosystems - A review. For Ecol Manag 358:248-260

Berg B, Johansson M-B, Ekbohm G, McClaugherty C, Rutigliano F, De Santo AV (1996) Maximum decomposition limits of forest litter types: a synthesis. Can J Bot 74:659-672

Berg B, McClaugherty C (2014) Plant Litter. DOI: 10.1007/978-3-642-38821-7_1.

Binkley D, Cromack K Jr, Baker DD (1994) Nitrogen fixation by red alder: biology, rates, and controls. In: Hibbs DE, DeBell DS, Tarrant RF (eds) The Biology and Management of Red Alder. Oregon State University Press, pp 57-72

Bödeker ITM, Clemmensen KE, de Boer W, Martin F, Olson Å, Lindahl BD (2014) Ectomycorrhizal Cortinarius species participate in enzymatic oxidation of humus in northern forest ecosystems. New Phytol 203:245-256

Bonnarme P, Jeffries TW (1990) Mn(II) regulation of lignin peroxidases and manganese-dependent peroxidases from lignindegrading white rot fungi. Appl Environ Microbiol 56:210-217

Brown JA, Glenn JK, Gold MH (1990) Manganese regulates expression of manganese peroxidase by Phanerochaete chrysosporium. J Bacteriology 172:3125-3130

Brown KJ, Hebda RJ (2002) Origin, development, and dynamics of coastal temperate conifer rainforests of southern Vancouver Island, Canada. Can J For Res 32:353-372

Buswell JA, Cai Y, Chang S (1995) Effect of nutrient nitrogen and manganese on manganese peroxidase and lactase production by Lentinula (Lentinus) edodes. FEMS Microbiol Lett 128:81-88

Buurman P, Jongmans AG (2005) Podzolisation and soil organic matter dynamics. Geoderma 125:71-83

Carpenter DN, Bockheim JG, Reich PF (2014). Soils of temperate rainforests of the North American Pacific Coast. Geoderma 230-231:250-264

Cohen R, Hadar Y, Yarden O (2001) Transcript and activity levels of different Pleurotus ostreatus peroxidases are differentially affected by $\mathrm{Mn}^{2+}$. Environ Microbiol 3:312-322

Craig ME, Turner BL, Liang C, Clay K, Johnson DJ, Phillips RP (2018) Tree mycorrhizal type predicts within-site variability in the storage and distribution of soil organic matter. Glob Change Biol 24:3317-3330

Davey MP, Berg B, Emmett BA, Rowland P (2007) Decomposition of oak leaf litter is related to initial litter Mn concentrations. Can J Bot 85:16-24

Doetterl S, Stevens A, Six J, Merckx R, Van Oost K, Pinto MC, Casanova-Katny A, Muñoz C, Boudin M, Venegas EZ, Boeckx P (2015) Soil carbon storage controlled by interactions between geochemistry and climate. Nat Geosci 8:780-785

Edwards IP, Zak DR, Kellner H, Eisenlord SD, Pregitzer KS (2011) Simulated atmospheric N deposition alters fungal community composition and suppresses ligninolytic gene expression in a northern hardwood forest. PLoS ONE 6:e20421

Loading [MathJax]/jax/output/CommonHTML/fonts/TeX/fontdata.js 
Entwistle EM, Romanowicz KJ, Argiroff WA, Freedman ZB, Morris JJ, Zak DR (2018a) Anthropogenic N deposition alters the composition of expressed class II fungal peroxidases. Appl Environ Microbiol 84:e02816-17

Entwistle EM, Zak DR, Argiroff WA (2018b) Anthropogenic N deposition increases soil C storage by reducing the relative abundance of lignolytic fungi. Ecol Monogr 88:225-244

Frey SD (2019) Mycorrhizal fungi as mediators of soil organic matter dynamics. Annu Rev Ecol Evol Syst 50:237-59

Gettemy JM, Ma B, Alic M, Gold MH (1998) Reverse transcription-PCR analysis of the regulation of the manganese peroxidase gene family. Appl Environ Microbiol 64:569-574

Jandl R, Lindner M, Vesterdal L, Bauwens B, Baritz R, Hagedorn F, Johnson DW, Minkkinen K, Byrne KA (2007) How strongly can forest management influence soil carbon sequestration? Geoderma 137:253-268

Jastrow D, Amonette JE, Bailey VL (2007) Mechanisms controlling soil carbon turnover and their potential application for enhancing carbon sequestration. Clim Chang 80:5-23

Johansson T, Nyman PO, Cullen D (2002) Differential regulation of mnp2, a new manganese peroxidase-encoding gene from the ligninolytic fungus Trametes versicolor PRL 572. Appl Environ Microbiol 68:2077-2080

Jones ME, LaCroix RE, Zeigler J, Ying SC, Nico PS, Keiluweit M (2020) Enzymes, manganese, or iron? Drivers of oxidative organic matter decomposition in soils. Environ Sci Tech 54:14114-14123

Jones ME, Nico PS, Ying S, Regier T, Thieme J, Keiluweit M (2018) Manganese-driven carbon oxidation at oxic-anoxic interfaces. Environ Sci Tech 52:12349-12357

Keiluweit M, Nico P, Harmon ME, Mao J, Pett-Ridge J, Kleber M (2015) Long-term litter decomposition controlled by manganese redox cycling. Proc Nat Academy Sci 112:E5253-E5260

Kellner H, Luis P, Pecyna MJ, Barbi F, Kapturska D, Krüger D, Zak DR, Marmeisse R, Vandenbol M, Hofrichter M (2014) Widespread occurrence of expressed fungal secretory peroxidases in forest soils. PloS ONE 9:e95557

Kranabetter JM (2019) Increasing soil carbon content with declining soil manganese in temperate rainforests: is there a link to fungal Mn? Soil Biol Biochem 128:179-181

Kranabetter JM, Banner A, de Groot A (2005) An assessment of phosphorus limitations to soil nitrogen availability across forest ecosystems of north coastal British Columbia. Can J For Res 35:530-540

Kranabetter JM, Harman-Denhoed R, Hawkins BJ (2019) Saprotrophic and ectomycorrhizal fungal sporocarp stoichiometry (C:N:P) across temperate rainforests as evidence of shared nutrient constraints among symbionts. New Phyt 221:482-492

Kranabetter JM, LePage P, Banner A (2013) Management and productivity of cedar-hemlock-salal scrub forests on the north coast of British Columbia. For Ecol Manag 308:161-168

Kranabetter JM, Sholinder A, de Montigny L (2020) Contrasting conifer species productivity in relation to soil carbon, nitrogen and phosphorus stoichiometry of British Columbia perhumid rainforests. Biogeosciences 17:1247-1260

Kyaschenko J, Clemmensen KE, Karltun E, Lindahl B (2017) Below-ground organic matter accumulation along a boreal fertility gradient relates to guild interaction within fungal communities. Ecol Lett 20:1546-1555

Lal R (2004) Soil carbon sequestration to mitigate climate change. Geoderma 123:1-22

Loading [MathJax]/jax/output/CommonHTML/fonts/TeX/fontdata.js

Page $11 / 21$ 
Lavallee JM, Soong JL, Cotrufo MF (2020) Conceptualizing soil organic matter into particulate and mineral-associated forms to address global change in the 21st century. Glob Chang Biol 26:261-273.

Lindo Z, Whiteley JA (2011) Old trees contribute bio-available nitrogen through canopy bryophytes. Plant Soil 342:141-148

Maaroufi NI, Nordin A, Palmqvist K, Hasselquist NJ, Forsmark B, Rosenstock NP, Wallander H, Gundale MJ (2019) Anthropogenic nitrogen enrichment enhances soil carbon accumulation by impacting saprotrophs rather than ectomycorrhizal fungal activity. Glob Chang Biol 25:2900-2914

Mayer M, Prescott CE, Abaker WEA, Augusto L, Cécillon L, Ferreira GWD, James J, Jandl R, Katzensteiner K, Laclau J-P, Laganière J, Nouvellon Y, Paré D, Stanturf JA, Vangeulova El, Vesterdal L (2020) Tamm Review: Influence of forest management activities on soil organic carbon stocks: A knowledge synthesis. For Ecol Manag 466:118-127

McArdle BH, Anderson MJ (2001) Fitting multivariate models to community data: A comment on distance-based redundancy analysis. Ecology 82:290-297

McNicol G, Bulmer C, D’Amore D, Sanborn P, Saunders S, Giesbrecht I, Arriola S-G, Bidlack A, Butman D, Buma B (2019) Large, climate-sensitive soil carbon stocks mapped with pedology informed machine learning in the North Pacific coastal temperate rainforest, Environ Res Lett 14:014004

Meeds J, Kranabetter JM, Zigg I, Dunn D, Miros F, Shipley P, Jones MD (2021). Phosphorus deficiencies invoke optimal allocation of exoenzymes by ectomycorrhizas. ISME J 15:1478-1489

Morgenstern I, Klopman S, Hibbett DS (2008) Molecular evolution and diversity of lignin degrading heme peroxidases in the agaricomycetes. J Mol Evol 66:243-257

Morrison EW, Frey SD, Sadowsky JJ, van Diepen LTA, Thomas WK, Pringle A (2016) Chronic nitrogen additions fundamentally restructure the soil fungal community in a temperate forest. Fungal Ecol 23:48-57

Oksanen J, Blanchet FG, Friendly M, Kindt R, Legendre P, McGlinn D, Minchin PR, O'Hara RB, Simpson GL, Solymos P, Stevens MHH, Szoecs E, Wagner H (2019) vegan: Community Ecology Package. R package version 2.5-6. https://CRAN.Rproject.org/package=vegan

Perakis SS, Matkins JJ, Hibbs DE (2012) Interactions of tissue and fertilizer nitrogen on decomposition dynamics of ligninrich conifer litter. Ecosphere 3:54

Perakis SS, Pett-Ridge JC (2019) Nitrogen-fixing red alder trees tap rock-derived nutrients. Proc Nat Acad Sci 116:5009-5014

Rasmussen C, Heckman K, Wieder WR, Keiluweit M, Lawrence CR, Berhe AA, Blankinship JC, Crow SE, Druhan JL, Hicks Pries CE, Marin-Spiotta E, Plante AF, Schädel C, Schimel JP, Sierra CA, Thompson A, Wagai R (2018) Beyond clay: towards an improved set of variables for predicting soil organic matter content. Biogeochemistry 137:297-306

Riley R, Salamov AA, Brown DW, Nagy LG, Floudas D, Held BW, Levasseur A, Lombard V, Morin E, Otillar R (2014) Extensive sampling of basidiomycete genomes demonstrates inadequacy of the white-rot/brown-rot paradigm for wood decay fungi. Proc Nat Acad Sci 111:9923-9928

R Core Team (2020) R: A language and environment for statistical computing. R Foundation for Statistical Computing, Vienna, Austria. URL https://www.R-project.org/

Sajedi T, Prescott CE, Seely B, Lavkulich LM (2012) Relationships among soil moisture, aeration and plant communities in natural and harvested coniferous forests in coastal British Columbia, Canada. J Ecol 100:605-618

Loading [MathJax]/jax/output/CommonHTML/fonts/TeX/fontdata.js 
Sanborn P, Lamontagne L, Hendershot W (2011) Podzolic soils of Canada: genesis, distribution, and classification. Can J Soil Sci 91:843-880

SAS Institute Inc (2021) SAS/STAT® User's Guide. Cary, NC

Scharlemann JPW, Tanner EVJ, Hiederer R, Kapos V (2014) Global soil carbon: understanding and managing the largest terrestrial carbon pool, Carbon Manag 5:81-91

Schmidt MWI, Torn MS, Abiven S, Dittmar T, Guggenberger G, Janssens IA, Kleber M, Kogel-Knabner I, Lehmann J, Manning DAC, Nannipieri P, Rasse DP, Weiner S, Trumbore SE (2011) Persistence of soil organic matter as an ecosystem property. Nature 1478:49-56

Soil Classification Working Group (1998) The Canadian System of Soil Classification, Agriculture and Agri-Food Canada Publication 1646 (Revised), Ottawa, Canada

Steffen KT, Hofrichter M, Hatakka A (2000) Mineralisation of ${ }^{14} \mathrm{C}$-labelled synthetic lignin and ligninolytic enzyme activities of litter-decomposing basidiomycetous fungi. Appl Microbiol Biotech 54:819-825

Stendahl J, Berg B, Lindahl BD (2017) Manganese availability is negatively associated with carbon storage in northern coniferous forest humus layers. Sci Reports 7:15487

Sterkenburg E, Clemmensen KE, Ekblad A, Finlay RD, Lindahl BD (2018) Contrasting effects of ectomycorrhizal fungi on early and late stage decomposition in a boreal forest. ISME J 12:2187-2197

Subedi P, Jokela EJ, Vogel JG, Bracho R, Inglett KS (2021) The effects of nutrient limitations on microbial respiration and organic matter decomposition in a Florida Spodosol as influenced by historical forest management practices. For Ecol Manag 479:118592

Sun OJ, Campbell J, Law BE, Wolf V (2004) Dynamics of carbon stocks in soils and detritus across chronosequences of different forest types in the Pacific Northwest, USA. Glob Chang Biol 10:1470-1481

Sun T, Cuib Y, Berg B, Zhang Q, Dong L, Wub Z, Zhang L (2019) A test of manganese effects on decomposition in forest and cropland sites. Soil Biol Biochem 129:178-183

Talbot JM, Martin F, Kohler A, Herissat B, Peay KG (2015) Functional guild classification predicts the enzymatic role of fungi in litter and soil biogeochemistry. Soil Biol Biochem 88:441-456

Taylor MK, Lankau RA, Wurzburger N (2016) Mycorrhizal associations of trees have different indirect effects on organic matter decomposition. J Ecol 104:1576-1584

Trum F, Titeux H, Cornelis J-T, Delvaux B (2011) Effects of manganese addition on carbon release from forest floor horizons. Can J For Res 41:643-648

Trum F, Titeux H, Ponette Q, Berg B (2015) Influence of manganese on decomposition of common beech (Fagus sylvatica L.) leaf litter during field incubation. Biogeochemistry 125:349-358

van Diepen LTA, Frey SD, Sthultz CM, Morrison EW, Minocha R, Pringle A (2015) Changes in litter quality caused by simulated nitrogen deposition reinforce the $\mathrm{N}$-induced suppression of litter decay. Ecosphere 6:1-16

Vares T, Hatakka A (1997) Lignin-degrading activity and ligninolytic enzymes of different white-rot fungi: effects of manganese and malonate. Can J Bot 75:61-71

Loading [MathJax]/jax/output/CommonHTML/fonts/TeX/fontdata.js 
Wang Y, Naumann U, Eddelbuettel D, Wilshire J, Warton D (2020) mvabund: Statistical Methods for Analysing Multivariate Abundance Data. $\mathrm{R}$ package version 4.1.6. https://CRAN.R-project.org/package=mvabund

Wardle DA, Jonsson M, Bansal S, Bardgett RD, Gundale MJ, Metcalfe DB (2012) Linking vegetation change, carbon sequestration and biodiversity: insights from island ecosystems in a long-term natural experiment. J Ecol 100:16-30

Watkinson S, Bebber D, Darrah P, Fricker M, Tlalka M, Boddy L (2006) The role of wood decay fungi in the carbon and nitrogen dynamics of the forest floor. In: Gadd GM (ed) Fungi in Biogeochemical Cycles. Cambridge University Press, Cambridge, pp 151-181

Whalen ED, Smith RG, Grandy AS, Frey SD (2018) Manganese limitation as a mechanism for reduced decomposition in soils under atmospheric nitrogen deposition. Soil Biol Biochem 127:252-263

Worrall JJ, Anagnost SE, Zabel RA (1997) Comparision of wood decay among diverse lignicolous fungi. Mycologia 89:199-219

Zak DR, Argiroff WA, Freedman ZB, Upchurch RA, Entwistle EM, Romanowicz KJ (2019) Anthropogenic N deposition, fungal gene expression, and an increasing soil carbon sink in the Northern Hemisphere. Ecology 100:e02804

\section{Tables}

Table 1

Selected soil properties averaged by substrate (forest floor and 0-20 cm mineral soil) for Brunisol and Podzol study sites across southern Vancouver Island (SE in brackets, $p$ value $<0.05$ in bold).

\begin{tabular}{|c|c|c|c|c|c|c|c|c|c|c|c|}
\hline $\begin{array}{l}\text { Soil } \\
\text { type }\end{array}$ & & Depth & $\begin{array}{l}\text { Exch. } \\
\text { Al }\end{array}$ & $\begin{array}{l}\text { Exch. } \\
\text { Mn }\end{array}$ & $\begin{array}{l}\text { Exch. } \\
\text { Fe }\end{array}$ & $\begin{array}{l}\text { Total } \\
\text { C }\end{array}$ & $\begin{array}{l}\text { Total } \\
\mathbf{N}\end{array}$ & C:N & $\begin{array}{l}\text { Inorganic } \\
\text { P }\end{array}$ & $\begin{array}{l}\text { Organic } \\
\mathrm{P}\end{array}$ & $\mathrm{pH}$ \\
\hline & (n) & $(\mathrm{cm})$ & $\begin{array}{l}(\mathrm{cmol} \\
\left.\mathrm{kg}^{-1}\right)\end{array}$ & $\begin{array}{l}(\mathrm{cmol} \\
\left.\mathrm{kg}^{-1}\right)\end{array}$ & $\begin{array}{l}(\mathrm{cmol} \\
\left.\mathrm{kg}^{-1}\right)\end{array}$ & $(\%)$ & $(\%)$ & (ratio) & $\begin{array}{l}\text { (mg kg- } \\
\left.{ }^{1}\right)\end{array}$ & $\begin{array}{l}(\mathrm{mg} \\
\left.\mathrm{kg}^{-1}\right)\end{array}$ & $\left(\mathrm{H}_{2} \mathrm{O}\right)$ \\
\hline \multicolumn{12}{|l|}{$\begin{array}{l}\text { Forest } \\
\text { floor }\end{array}$} \\
\hline Brunisol & 4 & $\begin{array}{l}1.5 \\
(0.3)\end{array}$ & $\begin{array}{l}0.3 \\
(0.1)\end{array}$ & $\begin{array}{l}3.74 \\
(0.66)\end{array}$ & $\begin{array}{l}0.11 \\
(0.05)\end{array}$ & $\begin{array}{l}42.2 \\
(1.4)\end{array}$ & $\begin{array}{l}1.18 \\
(0.04)\end{array}$ & $\begin{array}{l}35.8 \\
(2.8)\end{array}$ & 229 (19) & $\begin{array}{l}741 \\
(67)\end{array}$ & $\begin{array}{l}4.76 \\
(0.10)\end{array}$ \\
\hline Podzol & 5 & $\begin{array}{l}7.2 \\
(0.8)\end{array}$ & $\begin{array}{l}6.6 \\
(1.4)\end{array}$ & $\begin{array}{l}0.23 \\
(0.04)\end{array}$ & $\begin{array}{l}0.48 \\
(0.05)\end{array}$ & $\begin{array}{l}49.4 \\
(1.5)\end{array}$ & $\begin{array}{l}1.53 \\
(0.08)\end{array}$ & $\begin{array}{l}32.3 \\
(2.0)\end{array}$ & $127(7)$ & $\begin{array}{l}961 \\
(187)\end{array}$ & $\begin{array}{l}3.89 \\
(0.06)\end{array}$ \\
\hline$P$ value & & $<0.001$ & 0.068 & 0.001 & 0.003 & 0.054 & 0.069 & 0.383 & $<0.001$ & 0.570 & $<0.001$ \\
\hline \multicolumn{12}{|l|}{$\begin{array}{l}\text { Mineral } \\
\text { soil }\end{array}$} \\
\hline Brunisol & 5 & - & $\begin{array}{l}0.7 \\
(0.1)\end{array}$ & $\begin{array}{l}0.41 \\
(0.08)\end{array}$ & $\begin{array}{l}0.02 \\
(0.006)\end{array}$ & $\begin{array}{l}3.8 \\
(0.3)\end{array}$ & $\begin{array}{l}0.13 \\
(0.01)\end{array}$ & $\begin{array}{l}29.2 \\
(1.7)\end{array}$ & $665(74)$ & $\begin{array}{l}173 \\
(16)\end{array}$ & $\begin{array}{l}4.89 \\
(0.09)\end{array}$ \\
\hline Podzol & 5 & - & $\begin{array}{l}5.2 \\
(0.5)\end{array}$ & $\begin{array}{l}0.02 \\
(0.004)\end{array}$ & $\begin{array}{l}0.29 \\
(0.03)\end{array}$ & $\begin{array}{l}7.9 \\
(0.6)\end{array}$ & $\begin{array}{l}0.31 \\
(0.03)\end{array}$ & $\begin{array}{l}25.5 \\
(0.9)\end{array}$ & $136(41)$ & $\begin{array}{l}326 \\
(39)\end{array}$ & $\begin{array}{l}4.56 \\
(0.05)\end{array}$ \\
\hline $\mathrm{P}$ value & & & $<0.001$ & 0.005 & 0.001 & 0.007 & 0.016 & 0.364 & 0.006 & 0.071 & 0.095 \\
\hline
\end{tabular}


Table 2

Linear mixed effects statistical model results by substrate (forest floor and $0-20 \mathrm{~cm}$ mineral soil) for an Mn amendment and inoculum treatment (15 week laboratory incubation) on Mn-peroxidase activity and exchangeable Mn concentrations. (Soil type $=$ Brunisol vs. Podzol, $p$ values $<0.05$ in bold) .

\begin{tabular}{|c|c|c|c|c|c|c|}
\hline & \multicolumn{3}{|c|}{ Forest floor } & \multicolumn{3}{|c|}{ Mineral soil } \\
\hline & $\mathrm{df}$ & F value & $P$ value & $\mathrm{df}$ & F value & $P$ value \\
\hline \multicolumn{7}{|c|}{ Mn-peroxidase activity } \\
\hline Soil Type & 7 & 35.17 & $<0.001$ & 8 & 2.61 & 0.145 \\
\hline Mn amendment & 21 & 13.00 & 0.002 & 24 & 0.03 & 0.869 \\
\hline $\begin{array}{l}\text { Soil Type } \\
\times \\
M n\end{array}$ & 21 & 7.82 & 0.011 & 24 & 6.88 & 0.015 \\
\hline Inoculum & 21 & 0.29 & 0.595 & 24 & 2.44 & 0.132 \\
\hline $\begin{array}{l}\text { Soil Type } \\
\times \\
\text { Inoculum }\end{array}$ & 21 & 0.07 & 0.795 & 24 & 0.25 & 0.622 \\
\hline $\begin{array}{l}\mathrm{Mn} \\
\times \\
\text { Inoculum }\end{array}$ & 21 & 0.19 & 0.667 & 24 & 1.21 & 0.281 \\
\hline $\begin{array}{l}\text { Soil Type } \\
\times \\
\mathrm{Mn} \\
\times \\
\text { Inoculum }\end{array}$ & 21 & 0.15 & 0.698 & 24 & 0.00 & 0.959 \\
\hline \multicolumn{7}{|c|}{ Exchangeable Mn } \\
\hline Soil Type & 7 & 16.33 & 0.005 & 8 & 0.34 & 0.576 \\
\hline Mn amendment & 21 & 83.51 & $<0.001$ & 24 & 47.80 & $<0.001$ \\
\hline $\begin{array}{l}\text { Soil Type } \\
\times \\
M n\end{array}$ & 21 & 57.54 & $<0.001$ & 24 & 14.27 & 0.001 \\
\hline Inoculum & 21 & 1.08 & 0.310 & 24 & 0.05 & 0.830 \\
\hline $\begin{array}{l}\text { Soil Type } \\
\times \\
\text { Inoculum }\end{array}$ & 21 & 0.68 & 0.420 & 24 & 0.60 & 0.445 \\
\hline $\begin{array}{l}\text { Mn } \\
\times \\
\text { Inoculum }\end{array}$ & 21 & 0.25 & 0.624 & 24 & 0.01 & 0.913 \\
\hline $\begin{array}{l}\text { Soil Type } \\
\times \\
M n \\
\times \\
\text { Inoculum }\end{array}$ & 21 & 0.81 & 0.378 & 24 & 0.78 & 0.386 \\
\hline
\end{tabular}


Figures

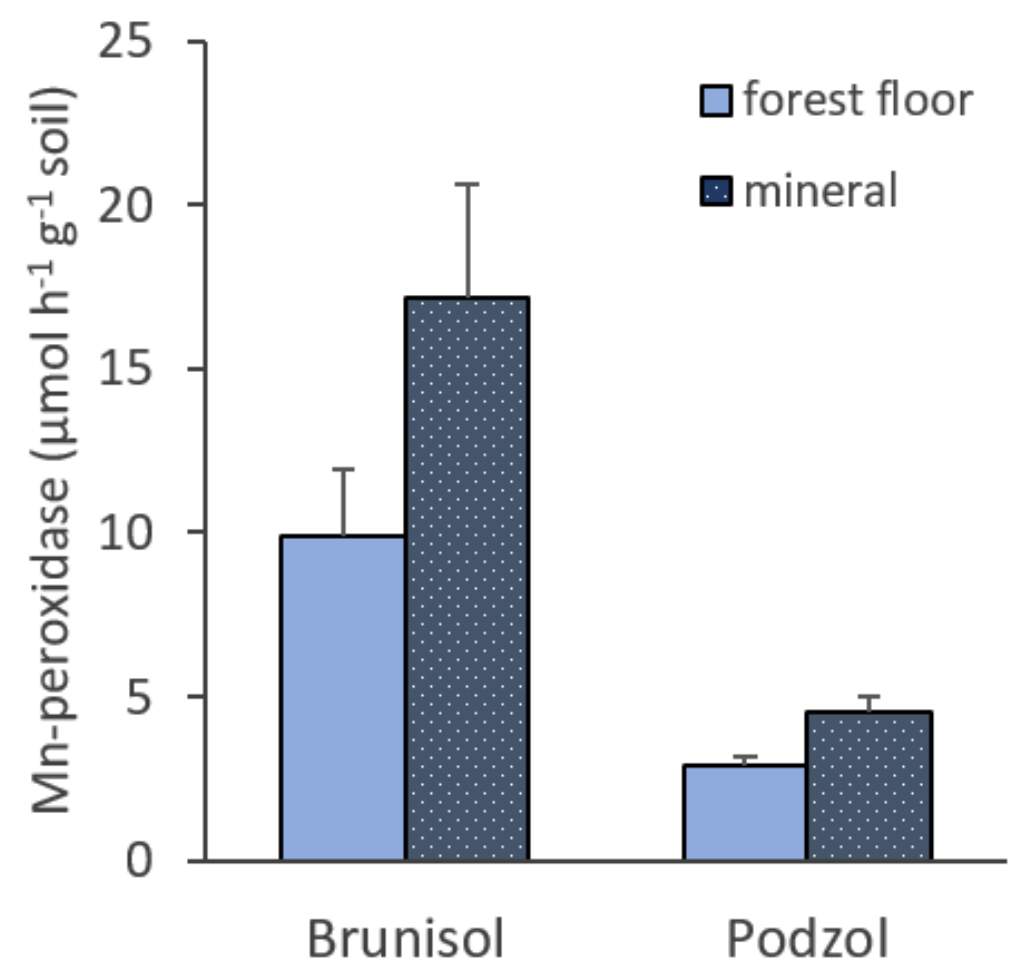

Figure 1

Average Mn-peroxidase activity of field soils for Brunisol and Podzol plots by substrate type (SE as bars; soil type $p=$ 0.002) 


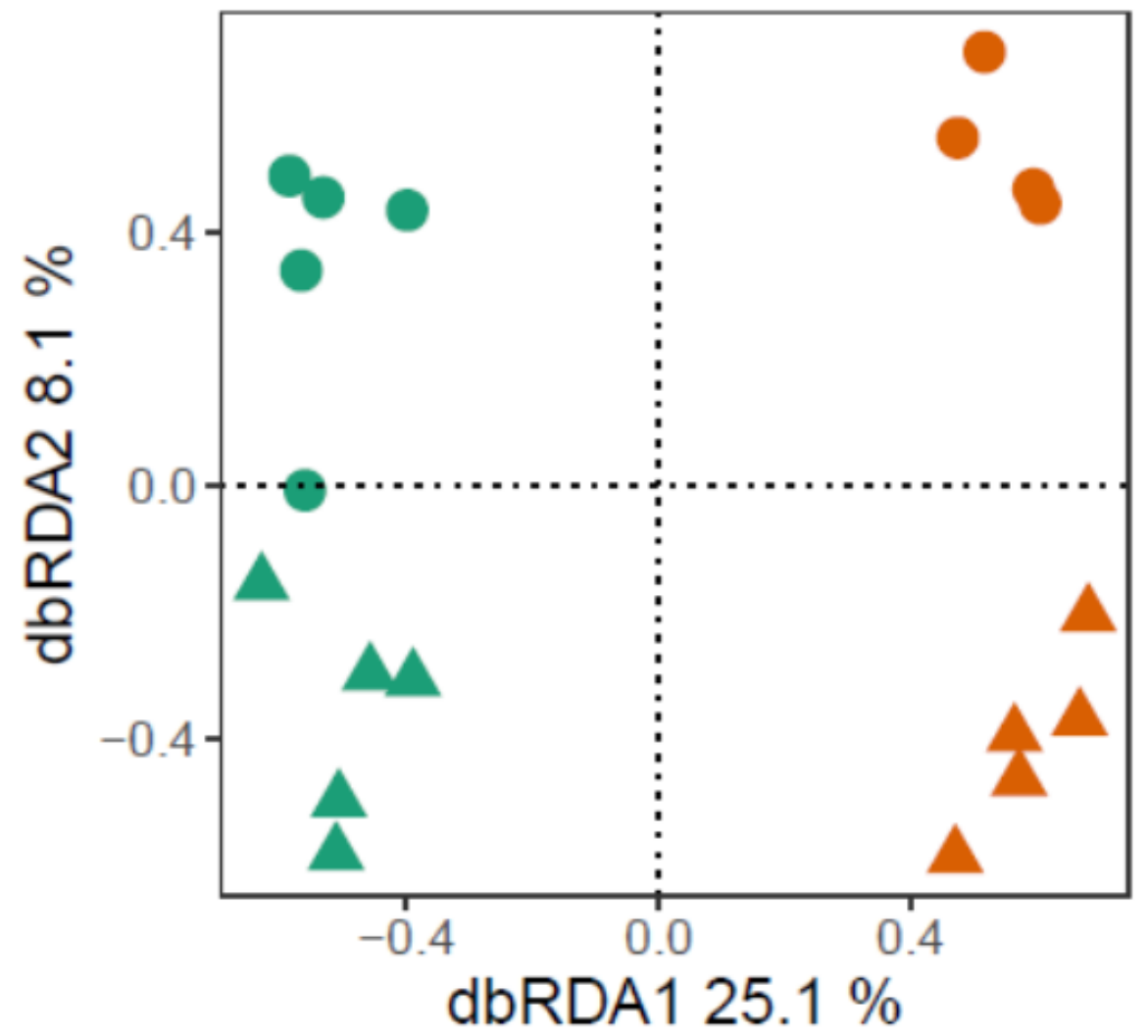

Figure 2

Ordination (distance-based redundancy analysis) of combined Agaricomycete saprotrophic and ectomycorrhizal fungal communities of field soils by soil type (Brunisol [orange] vs Podzol [green]) and substrate (forest floor [circle] and 0-20 cm mineral soil [triangle]). $\mathrm{N}=489$ spp., adj. $\mathrm{R} 2=28.4$ 


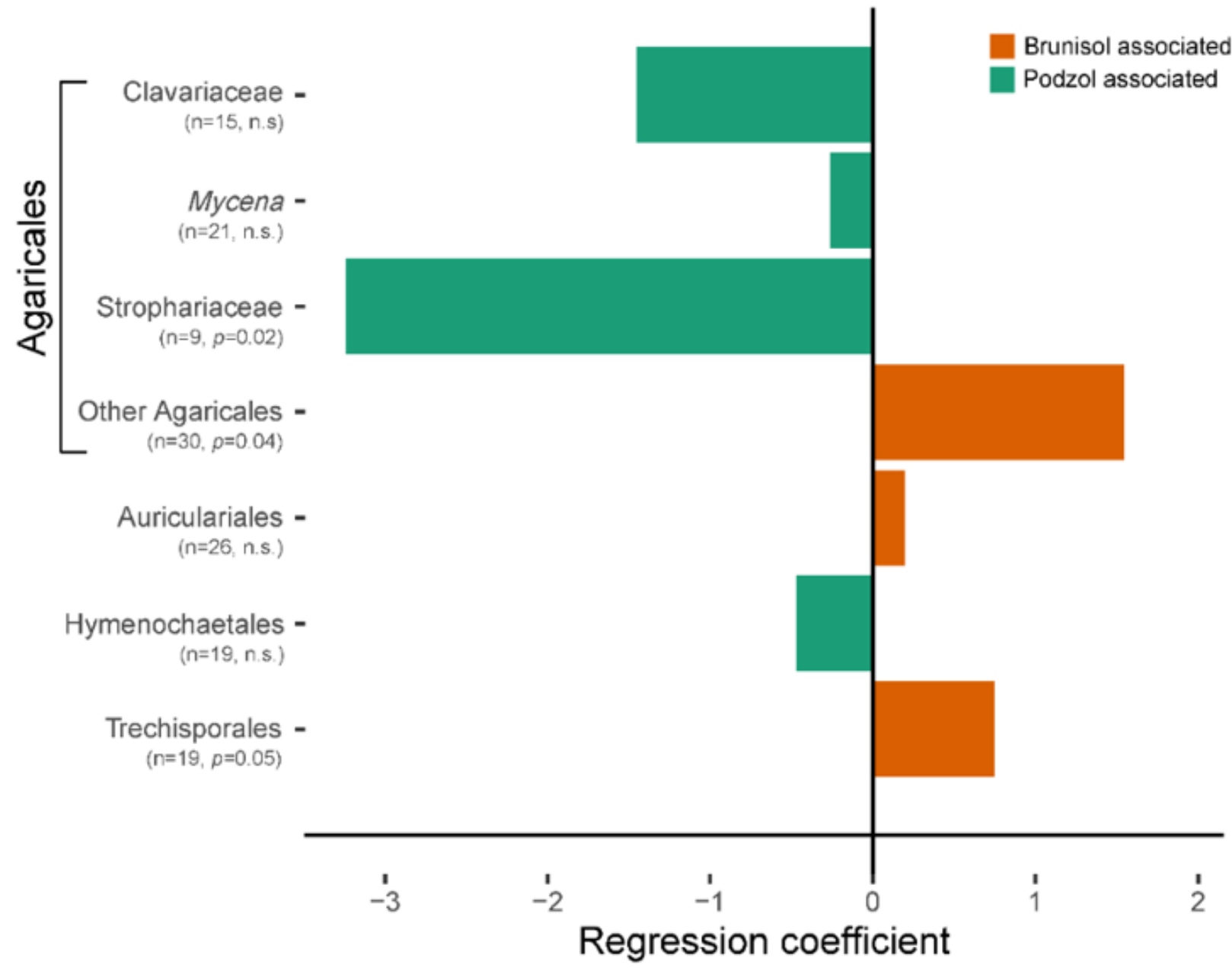

Figure 3

Regression coefficient plot by select Orders of saprotrophic fungi, with Agaricales split further into Families (Clavariaceae, Strophoriaceae and Other Agarics) or Genus (Mycena) ( $n=$ number of taxa per group). Counts were combined across substrates to portray overall response among soil types, and results ranked either positive, signifying greater presence in Brunisols, or negative (more prevalent in Podzols) 


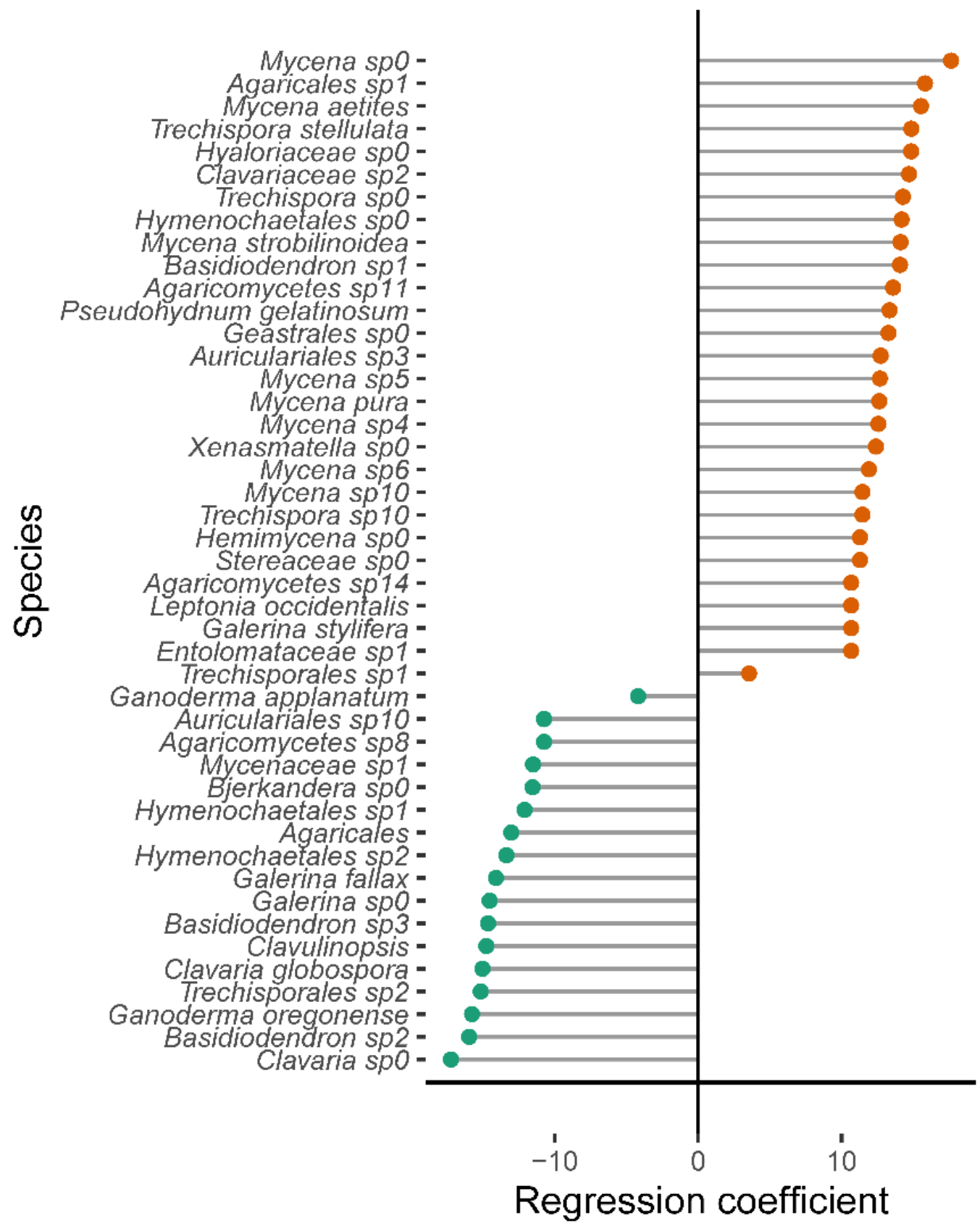

Figure 4

Regression coefficient plot of saprotrophic fungal species showing a difference in abundance between soil types (substrates combined). A positive coefficient signifies greater presence in Brunisols, whereas a negative coefficient depicts a stronger alignment with Podzols. Depicted species significant at $p<0.10$ 


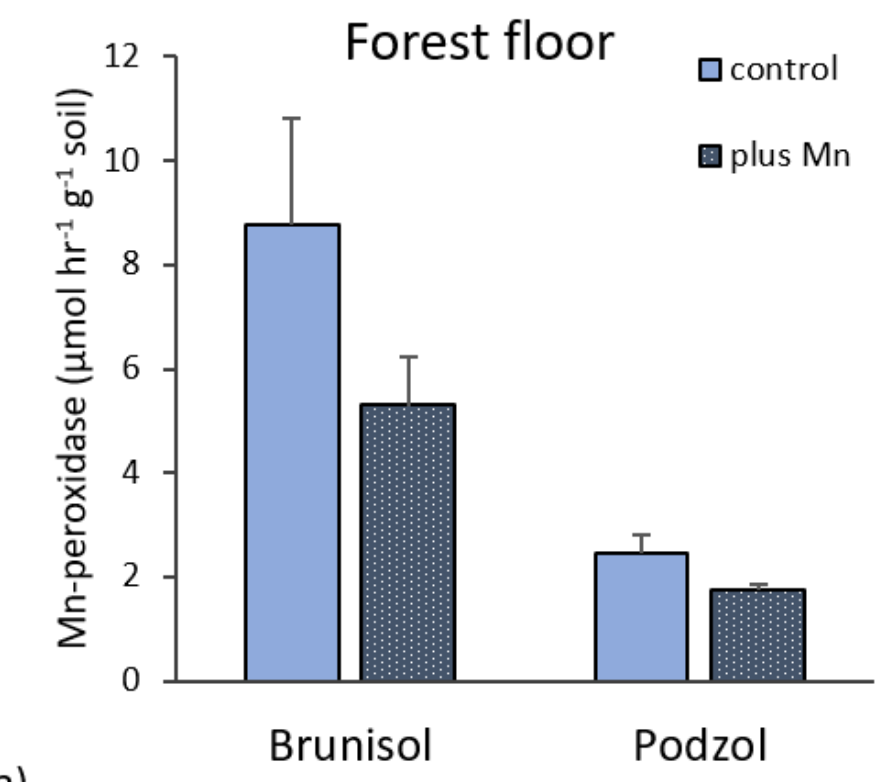

a)

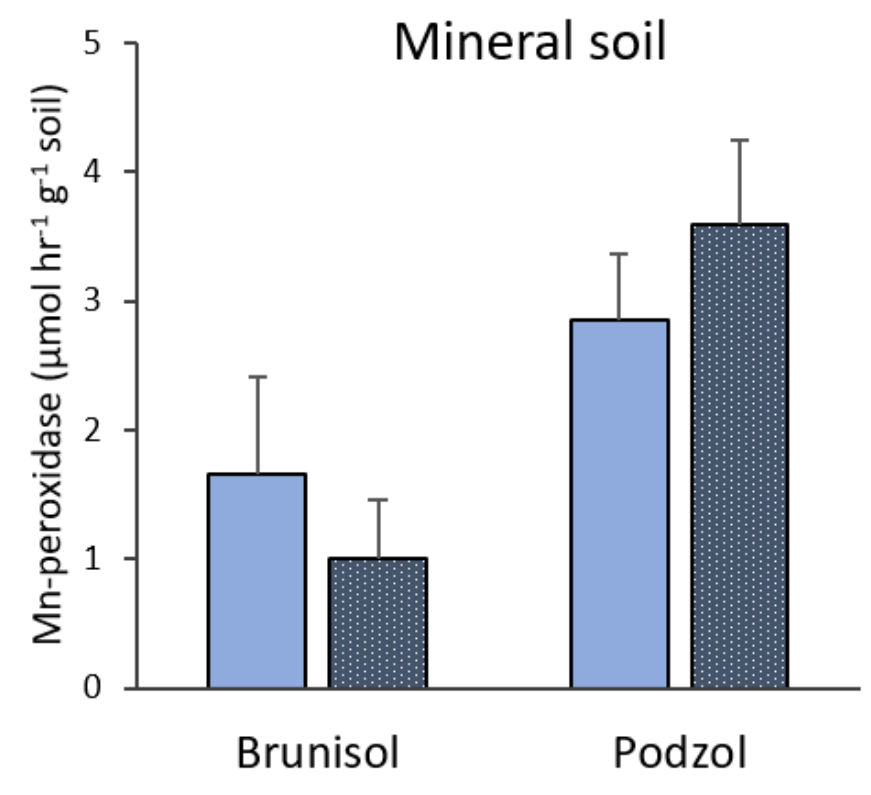

Figure 5

Difference in MnP activity of Brunisols and Podzols with added Mn after a 15 week laboratory incubation for a) forest floor and $b$ ) mineral soil ( $n=10$ per column [8 for Brunisol forest floor], averaged by Mn treatment with and without inoculum; SE as bars). Soil type $\times \mathrm{Mn}$ amendment interaction $\mathrm{p}<0.05$ for both subtrates, see Table 2

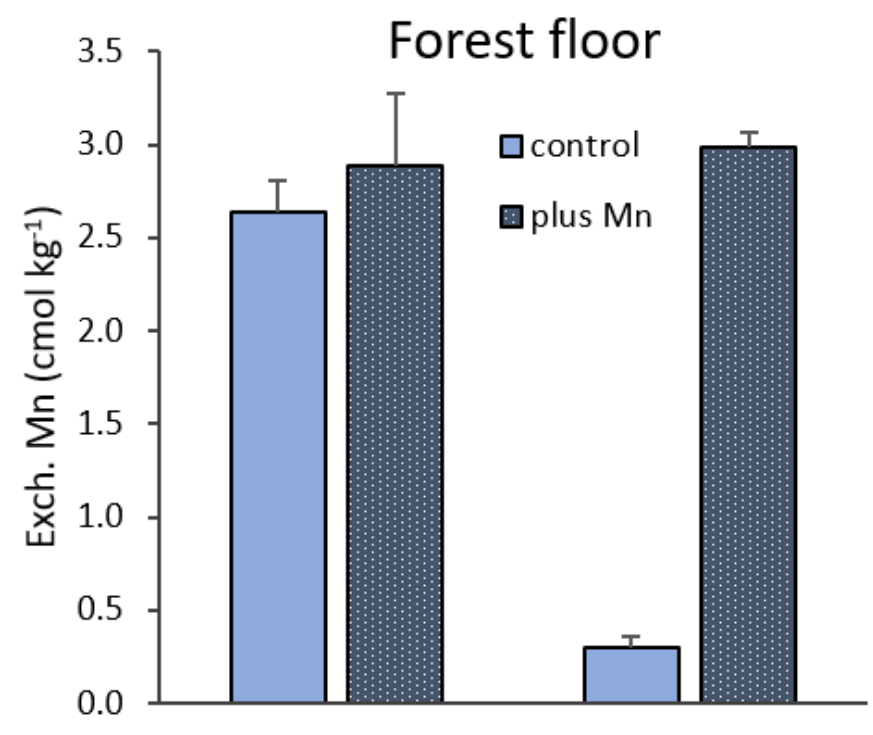

a)

Brunisol
Podzol

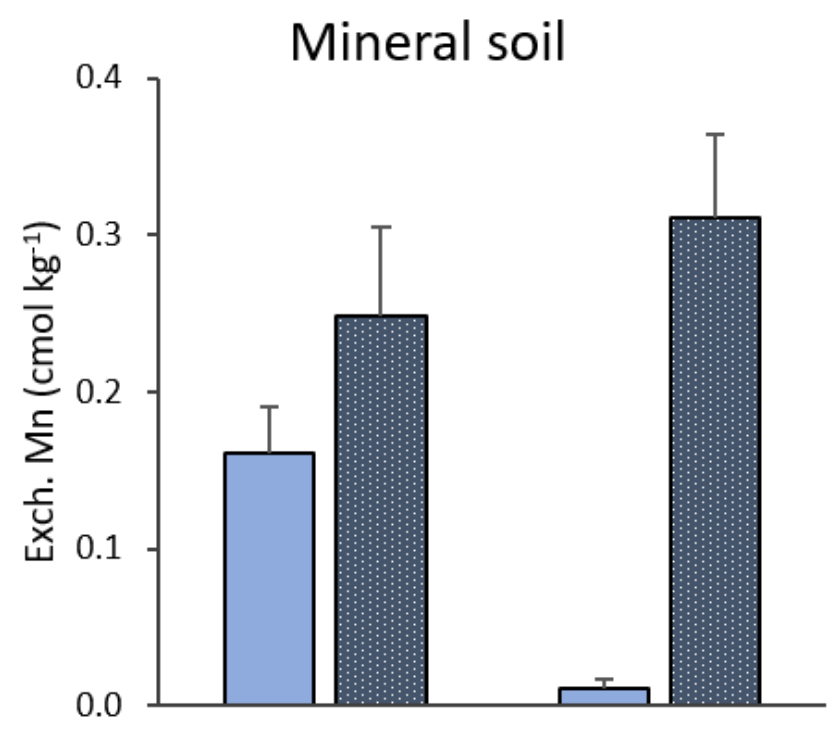

b)

Podzol

Figure 6

Exchangeable Mn concentrations of Brunisols and Podzols with an Mn amendment after a 15 week laboratory incubation for a) forest floor and $b$ ) mineral soil ( $n=10$ per column [8 for Brunisol forest floor], averaged by Mn treatment with and without inoculum; SE as bars). Soil type $\times \mathrm{Mn}$ amendment interaction $\mathrm{p}<0.05$ for both substrates, see Table 2 


\section{Supplementary Files}

This is a list of supplementary files associated with this preprint. Click to download.

- SIMaterialsandMethods.docx

- SupplementalTables.docx

- SupplementalFigures.docx 